\title{
Pathogenesis of acute ulceration response (AUR) in hybrid striped bass
}

\author{
Pareeya Udomkusonsri ${ }^{1,2}$, Edward J. Noga ${ }^{1, *}$, Nancy A. Monteiro-Riviere ${ }^{1}$ \\ ${ }^{1}$ Department of Clinical Sciences, College of Veterinary Medicine, North Carolina State University, 4700 Hillsborough Street, \\ Raleigh, North Carolina 27607, USA \\ ${ }^{2}$ Present address: Faculty of Veterinary Medicine, Department of Pharmacology, Kasetsart University, 50 Phahonyothin Road, \\ Chatuchak, Bangkok 10900, Thailand
}

\begin{abstract}
In a previous study, we discovered that acute confinement stress causes rapid ulceration of the fins of hybrid striped bass Morone saxatilis female $\times$ M. chrysops male (Noga et al. 1998. Vet Pathol 35:102-107). In this paper, we report the development of a reproducible model for studying this phenomenon in juvenile hybrid striped bass. We also determined how quickly ulceration could develop in acutely stressed fish and documented the sequential light microscopic and ultrastructural changes associated with this response. When hybrid striped bass were subjected to a standardized confinement protocol, the pathological response was extremely rapid (fin ulceration began to develop within 15 min of confinement). Grossly, the distal edges of the fins became blanched, and melanophores aggregated near the basement membrane and dermis after 15 min of confinement. Microscopically, the earliest detectable change in the fins, which occurred within 15 min of confinement, was swelling and loss of microridges of the outermost epidermal cells; this was followed by epidermal erosion. After 30 min of stress, epidermal ulceration developed at the distal edges of the fins. At this time, both necrotic and apoptotic epidermal cells were present. The middle and basal epidermal layers were severely spongiotic and the dermis and hypodermis were edematous. Over longer periods (up to $2 \mathrm{~h}$ ), lesions were similar but increasingly more severe, progressing from the distal edge of the fin towards the base. The response to acute stress showed a significant correlation between confinement period and severity of the pathological changes (epidermal degeneration, epidermal ulceration and leukocyte infiltration). Also, we demonstrated that epidermal damage was not restricted to the fins but also affected the body skin and eyes. The ventral area of the body and the corneal epithelium of stressed fish were ulcerated; however, skin on the head and operculum was not affected, suggesting a site-specific mode of damage. In stressed fish, epidermal ulceration was found in 67 to $97 \%$ of all fins, $88 \%$ of skin on the ventrum, and $67 \%$ of corneas, while control fish had only very mild epidermal ulceration in the few fish in which it was present (on 5 to $10 \%$ of the fins, but not on the ventral skin or corneas). Due to the widespread damage to epidermal tissues of the body surface, we have named this the acute ulceration response (AUR). Our study indicates that acute confinement can rapidly cause significant damage to epidermal and ocular epithelium. AUR might be a primary cause of morbidity in acutely stressed fish.
\end{abstract}

KEY WORDS: Skin ulceration $\cdot$ Striped bass $\cdot$ Acute stress $\cdot$ Pathology

\section{INTRODUCTION}

Hybrid striped bass (Morone saxatilis $\times$ M. chrysops) have great aquaculture potential and have become one of the fastest growing segments of US aquaculture (Harrell \& Webster 1997). The hybrid striped bass industry is now fifth in volume, and fourth in value, of all food fishes in the US (Carlberg et al. 2000). Hybrid striped bass demonstrate hybrid vigor, such as higher early growth rates, better survival and more resistance to disease than their parental species (Anderson et al. 2001). However, they are very susceptible to stress, which is often followed by an infectious disease outbreak (Plumb 1997). 
In intensive aquaculture, stress can be induced in many ways, including changes in the immediate physical environment ( $\mathrm{pH}$, temperature, water quality), fish interactions, and aquaculture practices (handling, transport and crowding). Acute confinement is one of the most common stressors in routine culture practices such as grading, transport and vaccination. Acute stressors such as confinement often lead to an infectious disease epidemic. In a previous study, we discovered that a major reason that hybrid striped bass might be susceptible to infections after confinement was because confinement for as little as $2 \mathrm{~h}$ caused rapid sloughing of the epidermis on their fins (Noga et al. 1998). As the epidermis is a major source of host defenses, such as immunoglobulins, lectins, complementlike proteins, lysozyme and antimicrobial polypeptides (Yano 1996, Robinette \& Noga 2001), this response could have serious effects on fish health.

In the present study, we closely examined the histological and ultrastructural changes associated with this acute ulceration response (AUR) and documented that AUR affects not only the fins but also the skin on the body as well as the cornea.

\section{MATERIALS AND METHODS}

Experimental stress model. The reciprocal cross of hybrid striped bass (Morone saxatilis male $\times M$. chrysops female), 6 to $18 \mathrm{mo}$ old and 70 to $110 \mathrm{~mm}$ in total length, were maintained in a 7601 holding (acclimating) tank at $14^{\circ} \mathrm{C}$. Fish were fed a commercial feed at approximately $2 \%$ of their body weight daily and maintained on a $12 \mathrm{~h}$ light:12 h dark photoperiod. The low temperature and restricted feed provided a constant supply of small, similar-size fish. For experiments, fish were acclimated to a $1500 \mathrm{l}$ freshwater tank; over a 2 wk period, the water temperature was gradually raised to $27^{\circ} \mathrm{C}$. Food was withheld on the day of the experiment. Water quality during all experiments was as follows: dissolved oxygen 6.8 to $7.5 \mathrm{mg}$ $\mathrm{l}^{-1}$, temperature $27^{\circ} \mathrm{C}, \mathrm{pH} 6.65$ to 6.87 , unionized ammonia $<0.001 \mathrm{mg} \mathrm{l}^{-1}$ and nitrite $<0.10 \mathrm{mg} \mathrm{l}^{-1}$.

In an initial experiment, 4 unstressed (control) fish were netted from the acclimating tank using a softmesh net. These fish were then immediately sacrificed with an anesthetic overdose (200 $\mathrm{mg} \mathrm{l}^{-1}$ tricaine buffered with $400 \mathrm{mg} \mathrm{l}^{-1}$ sodium bicarbonate). Another 4 fish were removed individually in the same manner and individually confined in plastic mesh boxes $(3.5 \times$ $14 \times 12 \mathrm{~cm})$. The boxes were agitated for $15 \mathrm{~s}$ every min during $2 \mathrm{~h}$ of confinement. Stressed fish were sacrificed with an anesthetic overdose. In a separate timecourse experiment, 8 fish were sacrificed with anesthetic overdose after 30,60, 90, or $120 \mathrm{~min}$ con- finement. After removal from the acclimating tank, 10 control (unstressed) fish were immediately sacrificed. In another experiment, to determine the minimum amount of time required for ulcers to develop, we exposed 4 fish to the same acute stress for $0,1,5,10$, 14, or $15 \mathrm{~min}$; fish were then examined for skin ulcers using fluorescein (see next subsection) and fixed for histological examination for skin ulcers.

Localization of ulcers. Recently, we have developed a means of rapidly locating ulcers on fish (Noga \& Udomkusonsri 2002). By staining fish with fluorescein, a nontoxic fluorescent dye, we can precisely identify even microscopic ulcers, which are not visible to the naked eye. In selected fish, we used fluorescein to localize skin ulcers. Immediately after stress exposure, fish were placed in a solution of $0.20 \mathrm{mg}$ fluorescein (AK-Fluor $^{\circledR}, 10 \%$ fluorescein sodium injection, $100 \mathrm{mg}$ $\mathrm{ml}^{-1}$, Akorn) $\mathrm{ml}^{-1}$ water for $6 \mathrm{~min}$, after which they were immediately rinsed with freshwater for $3 \mathrm{~min}$. The fish were then euthanized with buffered tricaine and immediately examined under ultraviolet light (Mineralight model UVGL-58) for skin or ocular damage.

Histopathology. For light microscopy, eyes, fins, and skin tissues of the head, operculum and ventrum were fixed in $10 \%$ neutral buffered formalin, decalcified in $10 \%$ ethylenediaminetetraacetic acid (EDTA) in $0.1 \mathrm{M}$ phosphate buffer ( $\mathrm{pH} 7.2$ ), embedded in paraffin, and processed routinely. All sections were stained with hematoxylin and eosin (H\&E) or with periodic acid Schiff (PAS). All tissues except corneas were evaluated blindly, as described in Noga et al. (1998). Briefly, lesions were scored on a scale of 1 to 5 , where $1=$ minimal damage (1 to $20 \%$ of area affected by the lesion), $2=$ mild damage ( 21 to $40 \%$ of area affected by the lesion), $3=$ moderate damage (41 to $60 \%$ of area affected by the lesion), $4=$ severe damage (61 to $80 \%$ of area affected by the lesion) and $5=$ extremely severe damage (81 to $100 \%$ of area affected by the lesion). Eyes were not scored, but rather cross-sectioned and simply examined for presence or absence of corneal ulceration.

All fin and body skin tissues were oriented in the longitudinal plane and then evaluated for pathological changes, including epidermal degeneration, epidermal erosion, epidermal ulceration and leukocyte infiltration. Epidermal degeneration was defined as swollen epidermal cells (intracellular edema) with pyknotic nuclei. Epidermal erosion was identified by the sloughing of the epidermal layers, but with the basement membrane still intact. Epidermal ulceration was regarded as complete loss of all epidermal layers as well as the basement membrane. Leukocyte infiltration was defined as the presence of a greater number of leukocytes in the epidermal and dermal layers than 
those present in unstressed controls. The mean severity scores of the pathological changes (e.g. see Fig. 6) were the average of the severity score in all experimental fish.

Electron microscopy. For transmission electron microscopy (TEM), caudal fins were cut into small pieces $(\sim 1.0 \times 2.0 \mathrm{~mm})$ and fixed in McDowell's and Trump's fixative ( $4 \%$ formaldehyde and $1 \%$ glutaldehyde buffered in monobasic sodium phosphate, $\mathrm{pH} 7.2$ to 7.4) for at least $1 \mathrm{~h}$. Fin tissues were then decalcified in $0.1 \mathrm{M} \mathrm{EDTA}$ at $4^{\circ} \mathrm{C}$ for $1 \mathrm{wk}$ (Quilhac \& Sire 1999), and subsequently rinsed 3 times with $0.1 \mathrm{M}$ phosphate buffer ( $\mathrm{pH} 7.2$ to 7.4 ) for $15 \mathrm{~min}$ and post-fixed in $1 \%$ osmium tetroxide in the same buffer for $1 \mathrm{~h}$. The tissues were dehydrated in $50 \%$ ethanol for $15 \mathrm{~min}, 75 \%$ ethanol for $15 \mathrm{~min}, 95 \%$ ethanol for $15 \mathrm{~min}$ (twice), $100 \%$ ethanol for $30 \mathrm{~min}$ (twice), and 100\% acetone for $30 \mathrm{~min}$ (twice). They were then infiltrated in $50 \%$ Spurr resin (1 part Spurr in 1 part acetone) for $30 \mathrm{~min}$ and $100 \%$ Spurr for 60 min (twice), embedded in fresh Spurr, and polymerized at $70^{\circ} \mathrm{C}$ for $8 \mathrm{~h}$. Semithin sections, $0.5 \mu \mathrm{m}$ thick, were stained with $1 \%$ toluidine blue in $1 \%$ sodium borate. Ultrathin sections, $90 \mathrm{~nm}$ thick, were post-stained with uranyl acetate and lead citrate for examination with a Philips 208S transmission electron microscope.

For scanning electron microscopy (SEM), caudal fins were fixed in McDowell's and Trump's fixative for at least $1 \mathrm{~h}$. Tissues were rinsed in $0.1 \mathrm{M}$ phosphate buffer for $30 \mathrm{~min}$, dehydrated in a graded series of alcohols and dried in a $\mathrm{CO}_{2}$ critical-point dryer (Ladd Research Industries). Tissues were mounted on stubs and sputter-coated. Observations were made with a Jeol JSM-35CF scanning electron microscope.

Statistical analyses. The exact unconditional test was used to analyze whether the proportion of epidermal damage in stressed fish was statistically greater than in control fish (Berger 1996). The test was performed for each type of epidermal damage and used the binomial one-sided model with Fisher's exactBoschloo as the test statistic with a $99.9 \%$ confidence interval. A 1-way ANOVA and Cochran-MantelHaenszel (CMH) test in SAS (Version 8, SAS Institute) was used to analyze the time course of confinement stress at 0, 30, 60, 90 and $120 \mathrm{~min}$. The 1-way ANOVA tested for significant differences of AUR severity in stressed fish compared to the control. The purpose of the $\mathrm{CMH}$ test was to determine whether each type of epidermal damage for each fin, body skin and corneal tissue was conditionally independent of the confinement period when adjusting for the control variable (the variation between replications) (Agresti 1996). We concluded that there was a linear association between treatment and epidermal damage when the $\mathrm{p}$-value of the correlation statistic was $<0.05$.

\section{RESULTS}

When hybrid striped bass were exposed to our acute confinement protocol, the pathological responses were highly reproducible. We observed a similar response after replicating this procedure over 8 times.

\section{Grossly visible lesions}

Initially, fish responded to confinement by immediately becoming excited after being placed into the individual confinement boxes. Within 15 min, the body skin darkened and a dark band appeared along the edge of the fins. Thereafter, the fish became fatigued, displayed slowed opercular movements, and remained on the bottom of the confinement box. Extensive epidermal erosion and ulceration of all fins was clearly evident under the stereomicroscope after $15 \mathrm{~min}$ of stress. Mild fin-splitting was detectable at the distal edges after 15 min confinement, and progressed intensely with time (Figs. 1 \& 2). After 30 min confinement, the edge of each fin became pale and exposed lepidotrichia (fin rays) were grossly visible in severely damaged fins. After fluorescein treatment, an intense
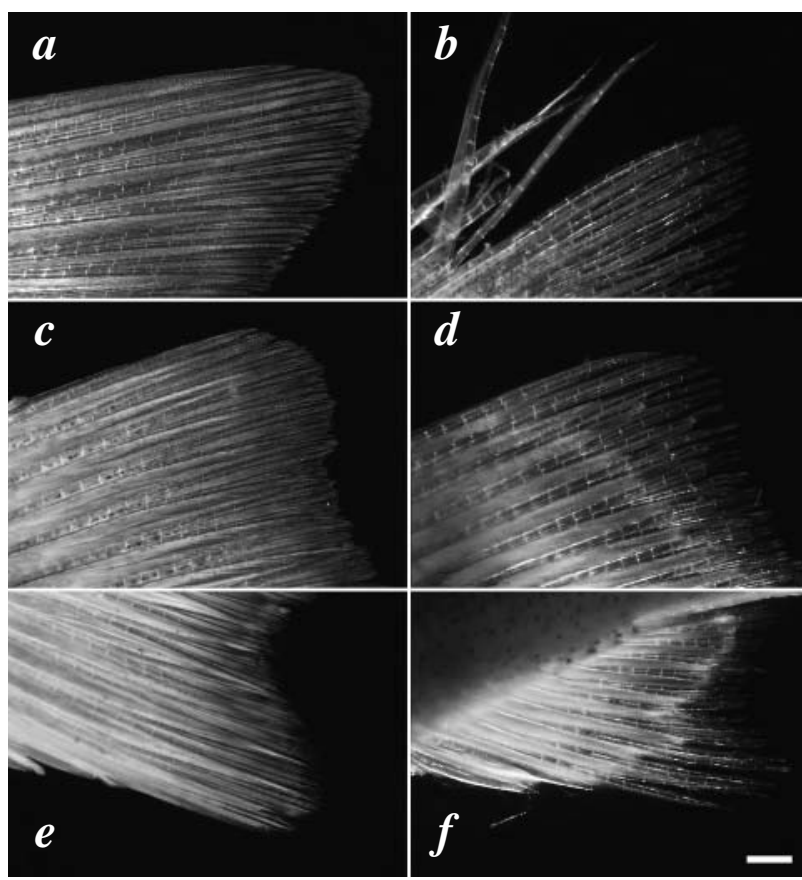

Fig. 1. Morone saxatilis male $\times M$. chrysops female. Hybrid striped bass fins of control and $2 \mathrm{~h}$ stressed fish under stereomicroscope. Stressed fins were ragged and split at distal edges. (a) Control caudal fin; (b) stressed caudal fin; (c) control dorsal fin; (d) stressed dorsal fin; (e) control anal fin; (f) stressed anal fin. Scale bar $=2 \mathrm{~mm}$ 


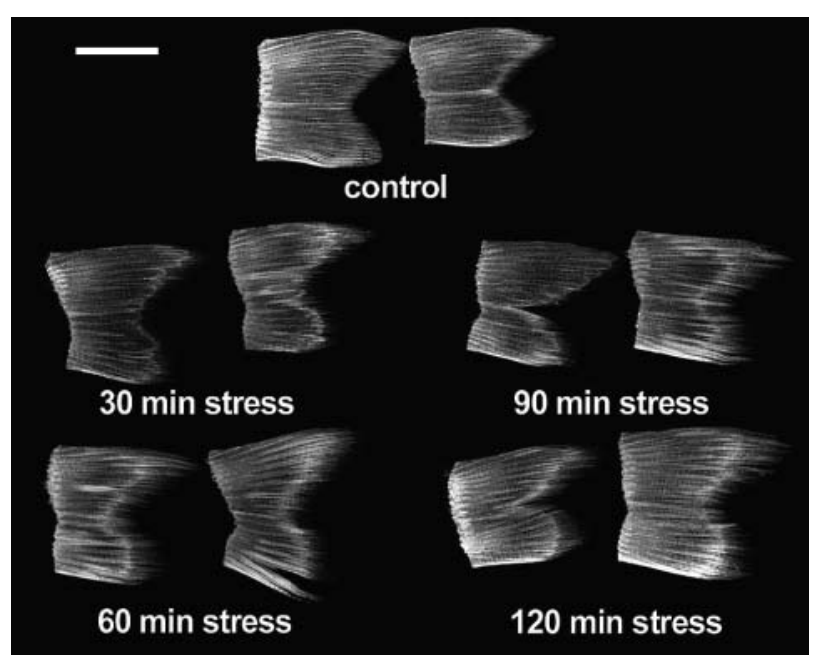

Fig. 2. Morone saxatilis male $\times M$. chrysops female. Caudal fins of hybrid striped bass showing acute ulceration response (AUR) after 0 (control), 30, 60, 90 and 120 min confinement, where fin tissue showed blanching and was ragged on distal edge. Epidermal erosion and ulceration developed in all fin tissues, as confirmed by histology. Scale bar $=1 \mathrm{~cm}$

green fluorescence was detected on the fins after $15 \mathrm{~min}$; later, both the ventral skin and cornea of the stressed fish also fluoresced (Fig. 3). Epidermal ulceration was confirmed histologically in these fluoresceinpositive areas. No fish died during the $2 \mathrm{~h}$ experimental stress.

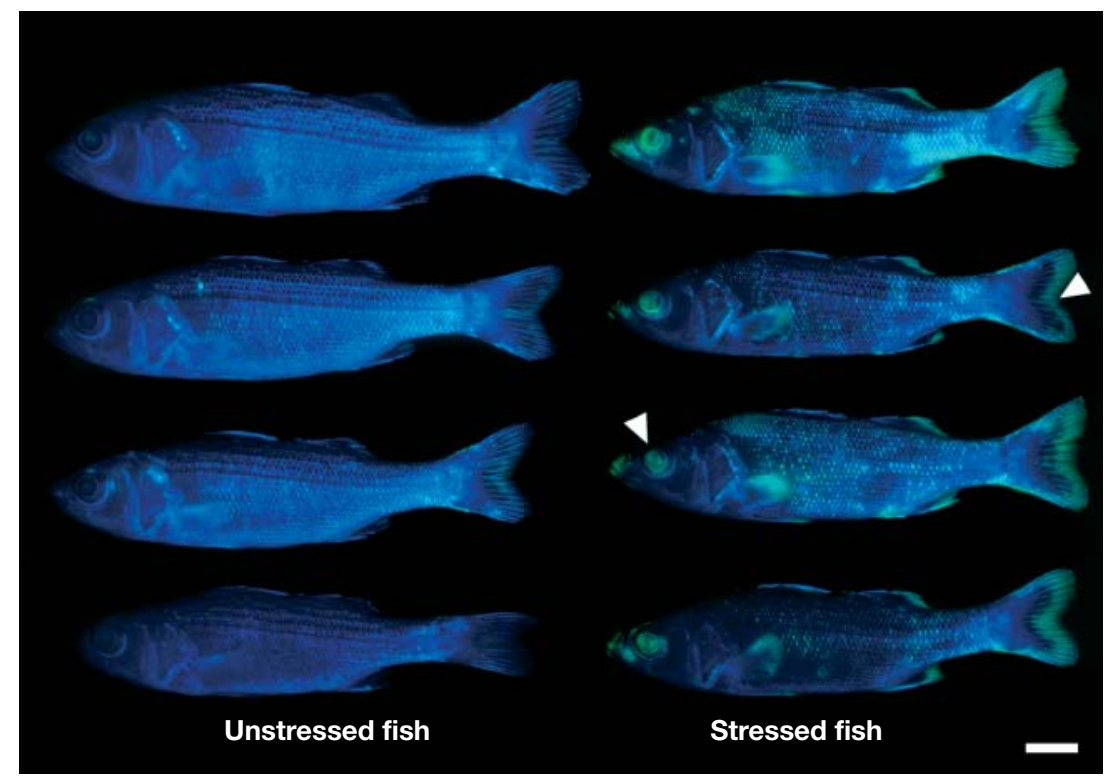

Fig. 3. Morone saxatilis male $\times$ M. chrysops female. Hybrid striped bass treated with fluorescein and photographed under short wavelength ultraviolet light with no filter, as described in Noga \& Udomkusonsri (2002). Left: control (unstressed) fish; right: fish stressed for $120 \mathrm{~min}$, note ulcers on fins, cornea (arrowheads) and ventrum (visible as intense green fluorescence). Scale bar $=1 \mathrm{~cm}$

\section{Histopathology}

Normal epidermis and corneal epithelium. Like that of other fishes, the skin of hybrid striped bass consists of 2 basic layers, the epidermis and dermis. A glycocalyx matrix usually covers the outer surface of the epidermis. Mucus cells, when present, stain positively with PAS. The fin epidermis consists of a nonkeratinized, stratified, squamous epithelium that is continuous with the epidermis of the body (Fig. $4 \mathrm{a}, \mathrm{b}$ ). The outermost surface of the epidermal cells has microridges (Fig. 4c) that are often arranged concentrically, forming maze-like patterns. Major structural components are desmosomes and tonofilaments (Fig. 4d) that firmly adhere the cells to each other. The basement membrane, lying between the epidermis and the dermis, is formed by densely packed fibrillar material and stains positively with PAS.

Like other teleosts, the dermis of hybrid striped bass fins has an outer stratum spongiosum and a reduced stratum compactum compared to the dermis on the body, which is composed of dense collagen fibers, elastic fibers, blood vessels and chromatophores (Groman 1982). Hybrid striped bass chromatophores include melanophores (containing melanin granules), xanthophores (containing pterin and carotenoid granules), and iridophores (with guanine or hypoxanthine platelets) (Groman 1982). The fins of hybrid striped bass, like those of other teleosts, are supported by fin rays or lepidotrichia, parallel skeletal structures of dermal origin (Beccera et al. 1983, Sharples \& Evans 1996) (Fig. 4a,b). The lepidotrichia are segmented along their length, with segments linked to each other by intersegmental joints of dense, fibrous connective tissue. Each lepidotrichium is composed of paired hemisegments, between which lies the intrasegmental region with nerves, blood vessels and loose connective tissue. Autophagocytic vesicles are present in the epidermal cells. Eosinophilic granular cells (mast cells), that stain metachromatically with toluidine blue, are distributed in the dermis and the basal layers of the epidermis. Leukocytes are sometimes present in the dermis and the basal epidermal layers of the fins.

The skin on the body of hybrid striped bass, like that of other teleosts, has a hypodermis (subcutaneous layer) below the dermis (Groman 1982). Scales are anchored within the dermal scale pockets, which lie between the stratum spongiosum and the basement membrane and are covered with epidermis. Scales are absent 

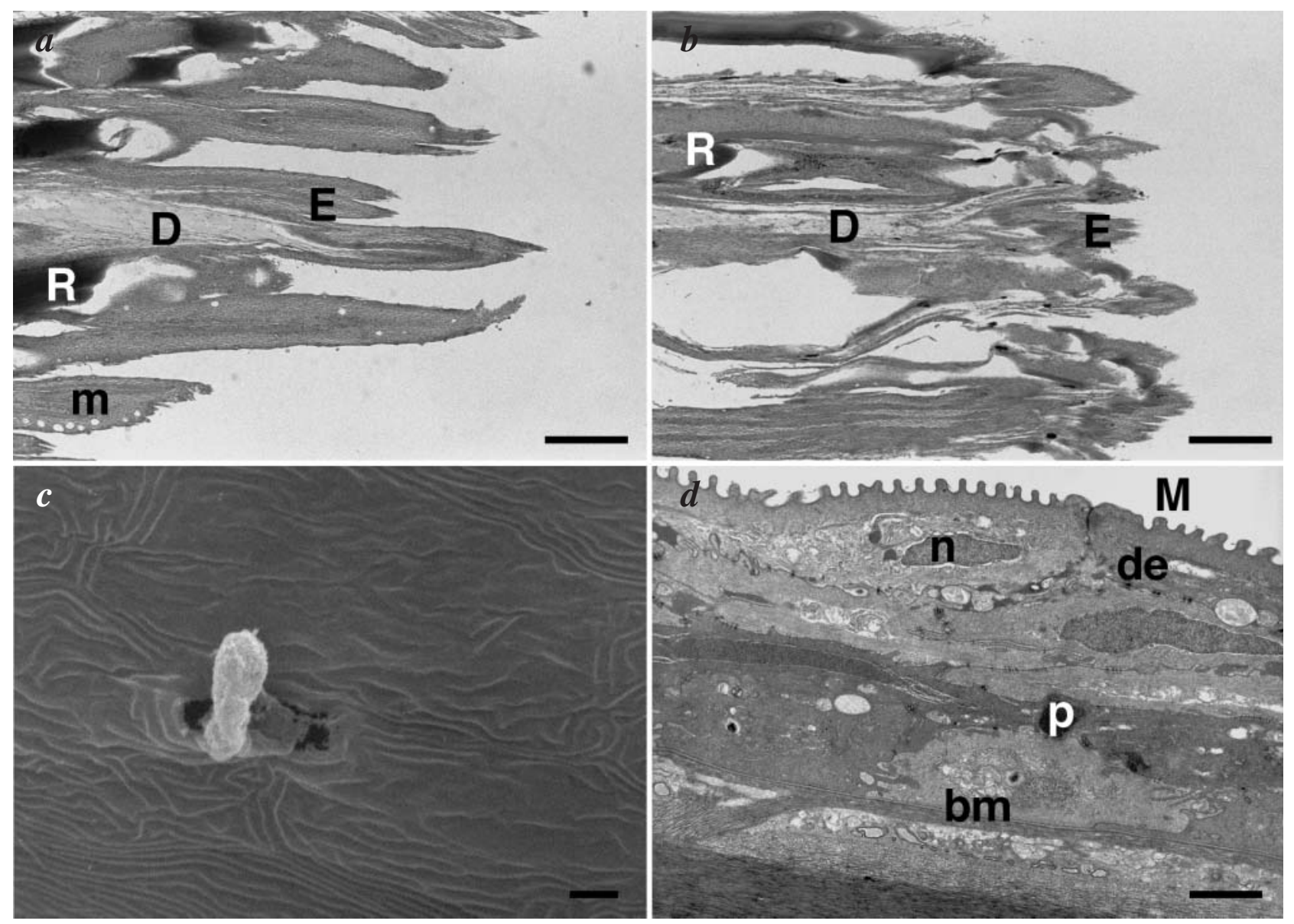

Fig. 4. Morone saxatilis male $\times$ M. chrysops female. Unstressed (control) fins of hybrid striped bass. (a) Normal caudal fin (H\&E). (b) Normal anal fin (H\&E). (c) SEM of normal caudal fin showing microridges on surface of epidermis and opening of mucus cell which is releasing mucus secretion. (d) TEM of epidermis of control caudal fin showing outer epidermis with numerous microridges. bm: basement membrane; de: desmosomes; m: mucus cells; n: nucleus of epidermal cell; p: autophagocytic vesicle. D: dermis; E: epidermis; M: microridges; R: fin ray. Scale bars = (a, b) $200 \mu \mathrm{m}$, (c) $1.5 \mu \mathrm{m}$, (d) $3 \mu \mathrm{m}$

from the head. The corneal epithelium is contiguous with the skin (Groman 1982) and covers the substantia propria (corneal stroma). The iris extends under the cornea and is a continuation of the pigmented cell layers (choroidea), which supply oxygen to the retina and inner pigmented cell layers.

Quantification of damage due to AUR. The prevalence of different degrees of pathological changes in control and $2 \mathrm{~h}$ stressed fish are quantitatively compared in Fig. 5. The most dramatic difference was epidermal ulceration, which was found in 67 to $97 \%$ of each fin type of stressed fish, while ulceration was only present in 0 to $10 \%$ of each fin type from control fish. These changes were significantly different between stressed and unstressed control fish for all fins, ventral skin and cornea of the eyes $(\mathrm{p}<0.05)$ (Fig. 5). In addition, the severity of ulceration in the unstressed fish was much less than in any of the stressed fish (Fig. 5). Incidence of leukocyte infiltration was also consider- ably greater in fins of stressed fish, occurring in 52 to $78 \%$ of various fins, compared to 0 to $15 \%$ of fins of unstressed fish; these changes were significantly different for all fins $(p<0.05)$. Changes in epidermal degeneration or erosion were less dramatic and in some cases were more common in control fish. For example, epidermal erosion was found in 0 to $40 \%$ of control fish and in 0 to $31 \%$ of stressed fish. The latter findings were not unexpected, as severely ulcerated fins would have relatively little erosion due to complete loss of the epithelium.

The severity of epidermal ulceration and leukocyte infiltration in all the fins of the stressed fish was also greater than in the fins of the control, unstressed fish (Fig. 6). Changes in epidermal degeneration or erosion were less dramatic, and in some cases were more common in control fish. In addition to the fin damage, more severe ulceration was observed in the ventral skin and corneal epithelium of stressed fish (Fig. 6). 
a Epidermal degeneration
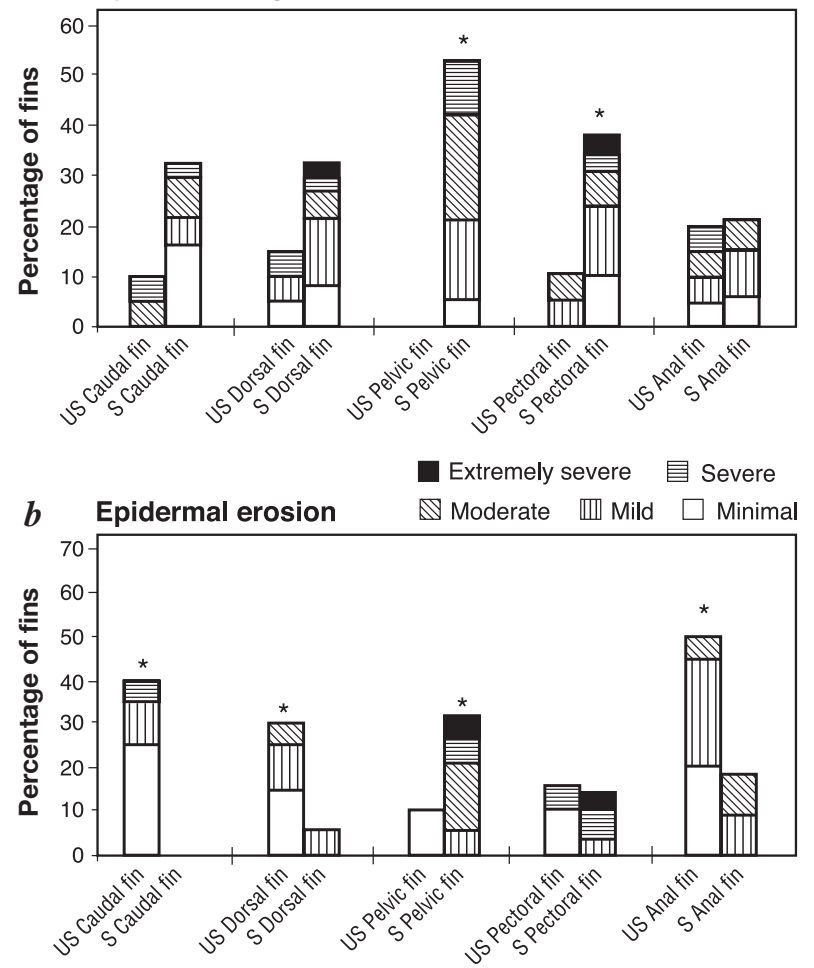

$c$
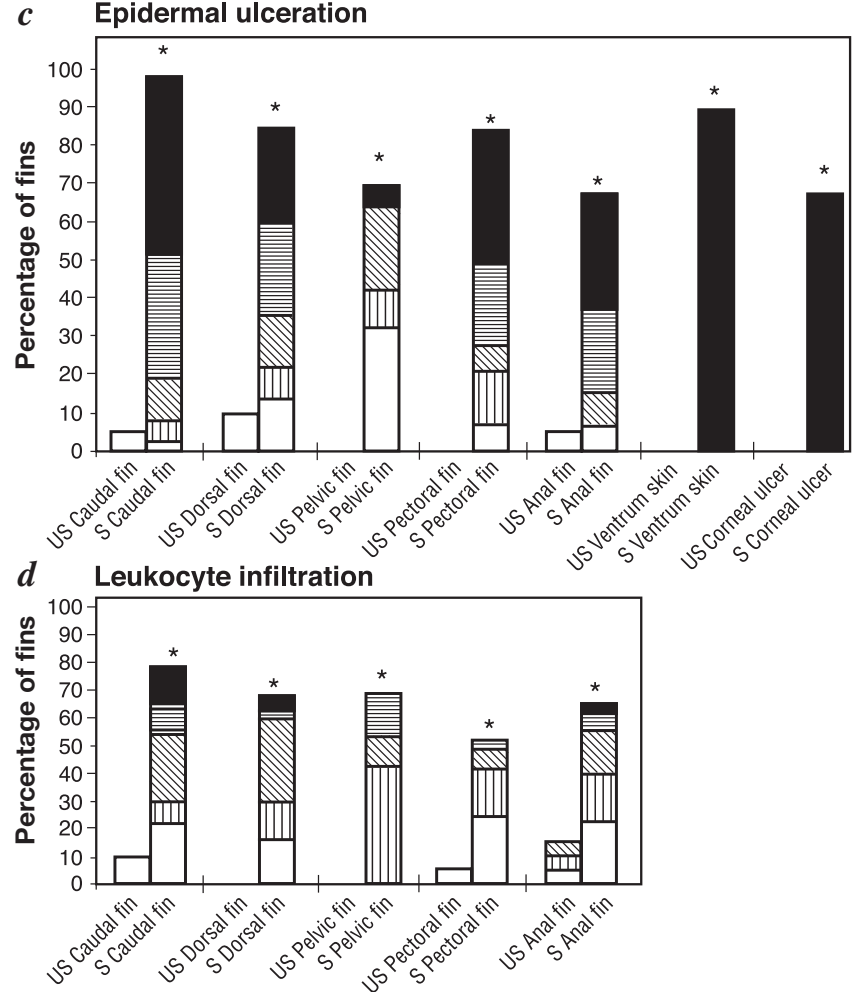

Fig. 5. Morone saxatilis male $\times M$. chrysops female. Prevalence of various degrees of (a) epidermal degeneration, (b) epidermal erosion, (c) epidermal ulceration, and (d) leukocyte infiltration on fins (a-d) and ventrum and cornea (c) of unstressed (US, control) and $2 \mathrm{~h}$-stressed (S) hybrid striped bass. *Mean prevalence of epidermal damage was significantly different in stressed versus unstressed fish (Fisher's exact-Boschloo test, $\mathrm{p}<0.05$ ). There were 8 replications and 32 fish in each group; data for all 8 experiments were combined for analysis

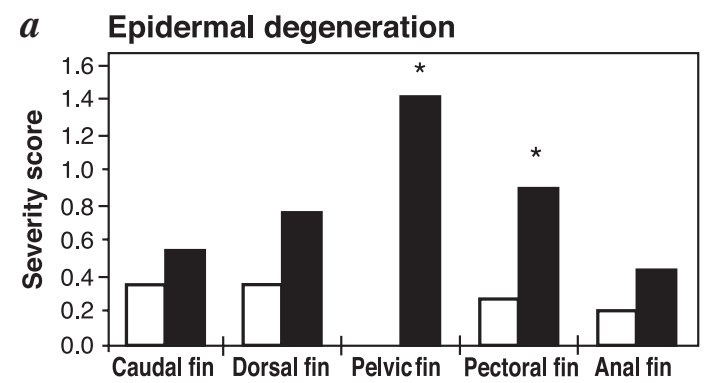

c Epidermal ulceration
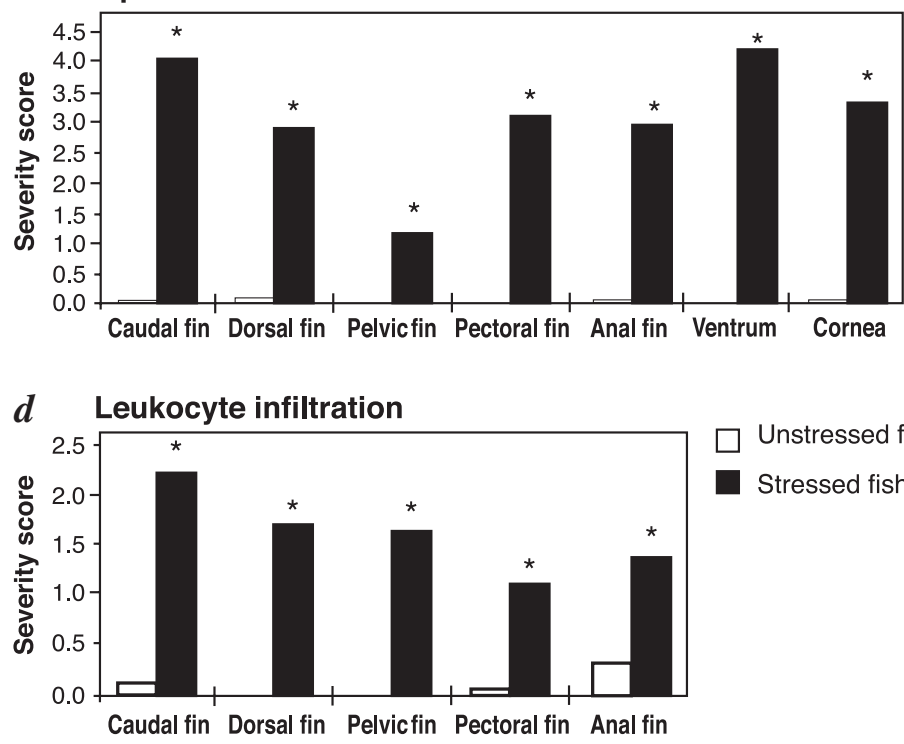

Unstressed fish

Stressed fish
Caudalfin Dorsalfin Pelvicfin Pectoralfin Anal fin

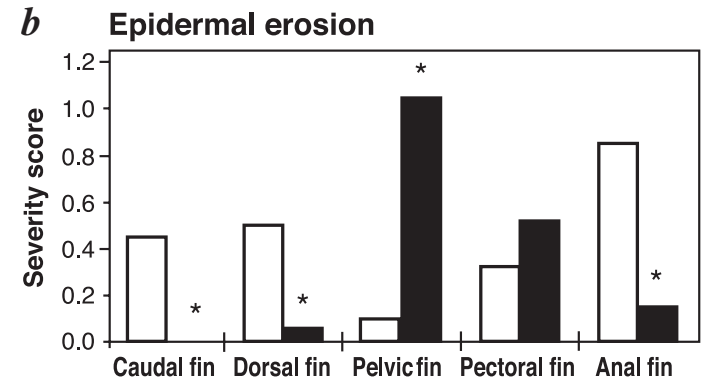

Fig. 6. Morone saxatilis male $\times M$. chrysops female. Mean severity score of (a) epidermal degeneration, (b) epidermal erosion, (c) epidermal ulceration, and (d) leukocyte infiltration on the fins (a-d) and ventrum and cornea (c) of unstressed (control) and $2 \mathrm{~h}$-stressed hybrid striped bass. *Significant difference between changes to stressed fish and unstressed fish (ANOVA, $\mathrm{p}<0.05)$. There were 8 replications and 32 fish in each group; data for all 8 experiments were combined for analysis 

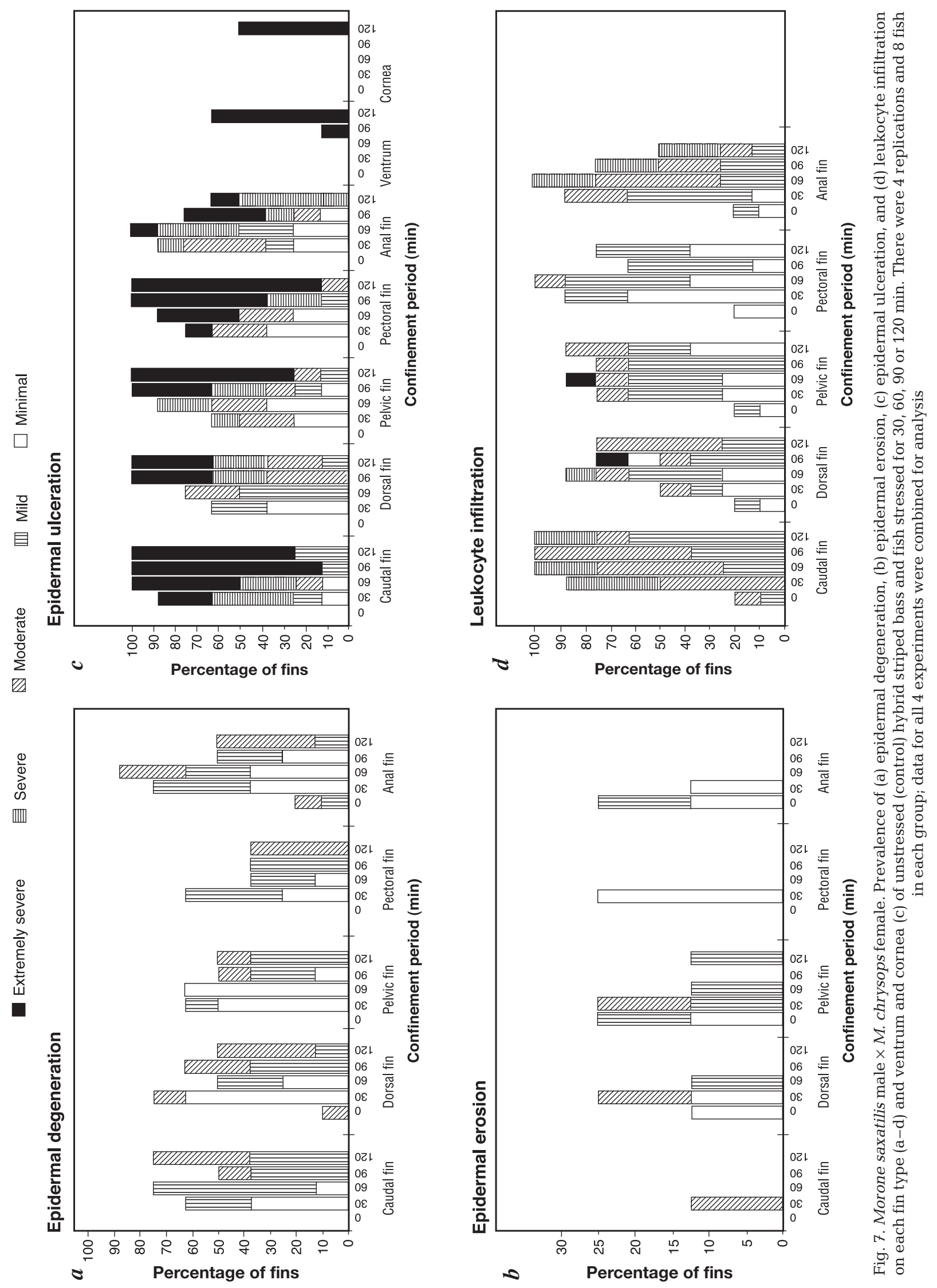
The prevalence of various degrees of pathological changes in stressed fish examined in the time-course experiment was also qualitatively greater than in control fish (Fig. 7). However, a trend in epidermal erosion was not apparent, probably since the stressed fish developed epidermal ulceration rather than erosion.

Statistical analysis of the mean severity scores in the time-course experiment showed a positive linear correlation between severity of pathological changes (epidermal degeneration, epidermal ulceration and leukocyte infiltration) and confinement period; thus, increasing confinement time led to more severe AUR (Fig. 8).

Qualitative changes due to AUR. Fish stressed for up to $14 \mathrm{~min}$ did not exhibit AUR, as evidenced by a negative response with the fluorescein test. However, fish stressed for 15 min developed AUR. This was further confirmed by histological examination of fins of fish stressed for 13,14, or $15 \mathrm{~min}$. After $15 \mathrm{~min}$, melanophores aggregated near the basement membrane and upper dermis of stressed fins, which caused fin-blanching. The earliest microscopically detectable sign of AUR lesions was swelling of the superficial epidermal cells, with affected cells at the distal edges of the fins appearing round (Fig. 9). The outermost swollen epidermal cells were sloughed, and rounded epidermal cell were attached to the adjacent cells by desmosomes (Fig. 9).

After 30 min confinement, the swollen epidermis became erosive, and the epidermis beneath the erosive area was devoid of microridges (Fig. 10a,b). Intercellular edema was present in the middle and basal layers of the epidermis. The basement membrane was still normal at the $30 \mathrm{~min}$ stress period. Some epidermal cells displayed detached desmosomes, large cytoplasmic vacuoles, nuclear shrinkage, loss of cytoplasmic organelles and swollen mitochondria. Both necrotic and apoptotic cells were present in the affected areas after 30 min confinement (Fig. 10c,d). Necrotic cells were swollen, with disruption of the cell membrane, increased electronlucency of the cytoplasm, and fragmentation of the nuclear chromatin. A large number of necrotic cells were found along the outer layers of epidermis. Apoptotic cells were characterized by cellular shrinkage and condensation of the cellular
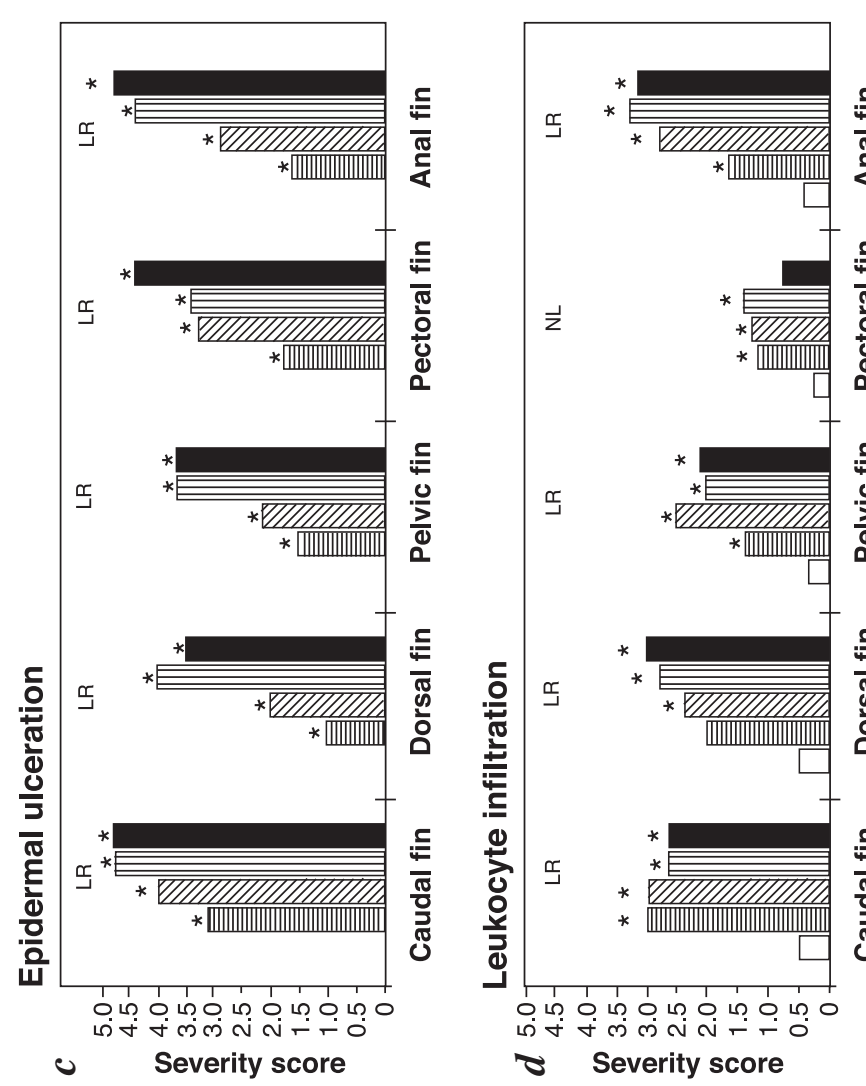

$\stackrel{\oplus}{\oplus}$

학

Q $\pi$

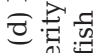

马े

d in

?ृ

ש

跣

드.

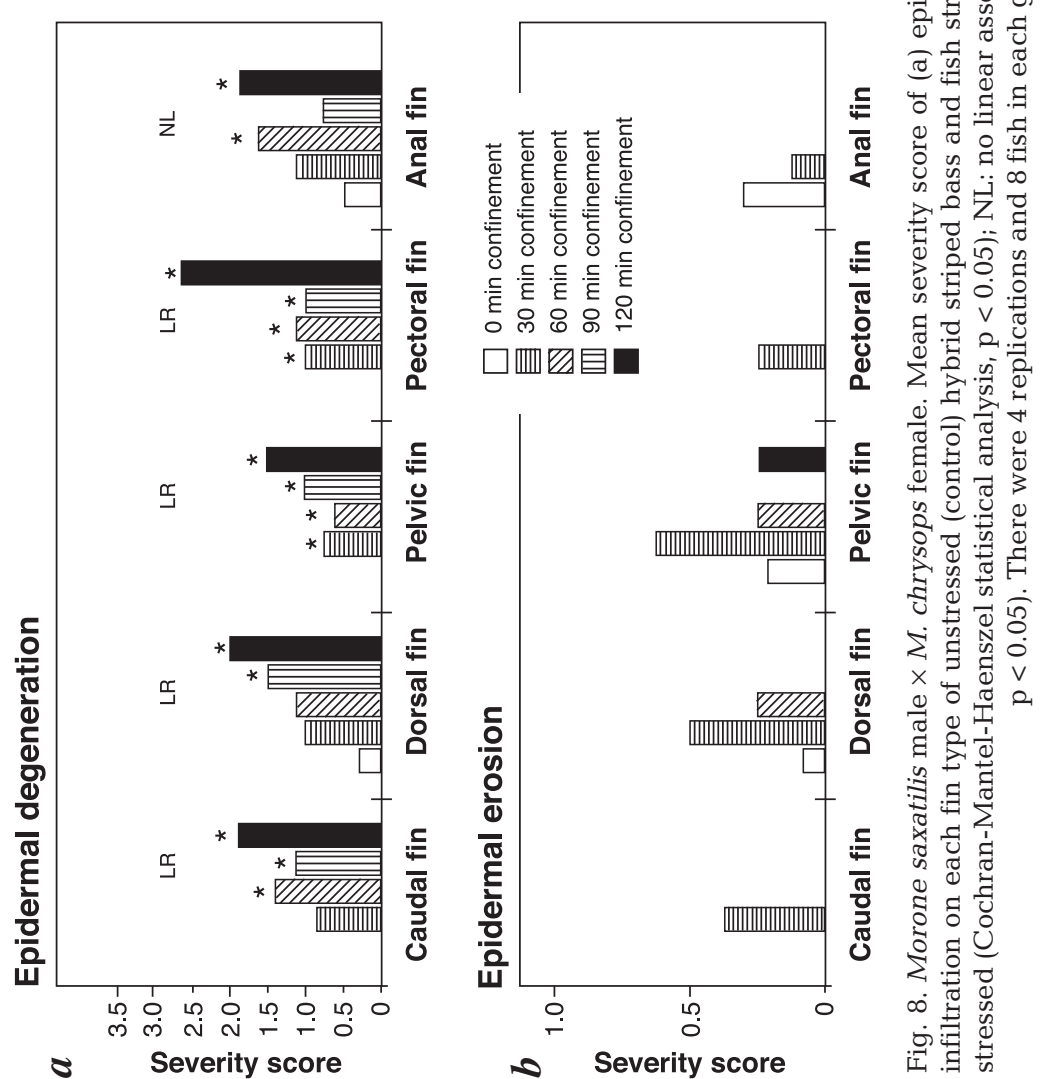



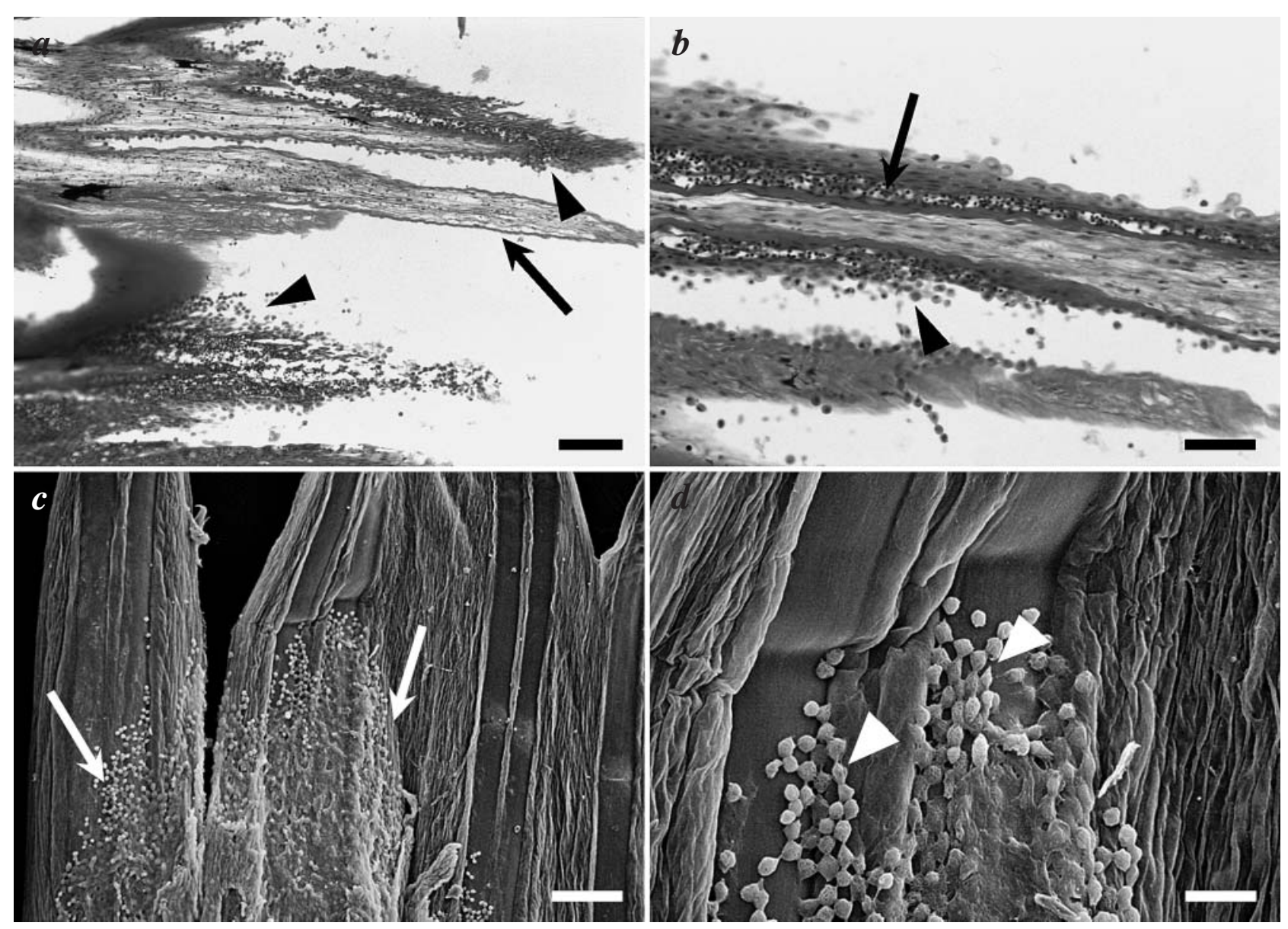

Fig. 9. Morone saxatilis male $\times$ M. chrysops female. Caudal fins of hybrid striped bass confined for 15 min. (a) Caudal fin showing epidermal erosion (arrowheads) and epidermal ulceration (arrow) of distal edge of fin (H\&E). (b) Swollen and sloughed outer epidermal cells (arrowhead); leukocytes have appeared in basal layers of epidermis and dermis (arrow). (c) SEM of caudal fin showing epidermal erosion and ulceration of distal edge (arrows). (d) SEM of caudal fin showing rounding epidermal cells (arrowheads); cells remain attached to each other by desmosomes. Scale bars = (a, c) $100 \mu \mathrm{m}$, (b) $260 \mu \mathrm{m}$, (d) $26 \mu \mathrm{m}$

components (Fig. 10c). Autophagocytic vesicles were also present in the stressed epidermis.

After $60 \mathrm{~min}$, epidermal ulceration became more prominent at the distal edges of the fins. After $90 \mathrm{~min}$, the most severely damaged areas, at the distal tips of the fins, were depicted by severe ulceration. Fin ulcers demonstrated complete loss of epidermis without an attached basement membrane; this was confirmed by PAS-staining and TEM. Apoptotic cells were focally scattered in the epidermis, while necrotic epidermal cells were present in much larger numbers, especially on the outer surface of the epidermis.

After $2 \mathrm{~h}$ stress, the hypodermis became edematous (Fig. 11a,c). Most of the $2 \mathrm{~h}$ stressed fish developed severe epidermal ulceration at the distal edge of the caudal fin (Fig. 11b,d). The epidermis was normal towards the peduncle. In stressed fins, leukocytes, including lymphocytes, appeared in the basal layers of the eroded epidermis and in the ulcerated areas of dermis, as well as in the dermis. Lymphocytes had a typical appearance, being round with a high nuclearto-cytoplasmic ratio and intensely basophilic nucleus surrounded by a homogenous, basophilic cytoplasm. Neutrophils, round cells with an eccentric, indented nucleus, as well as eosinophilic granular cells were also found in the dermis. While the epithelium on the head and the operculum appeared normal, the area above the anus was highly affected (Fig. 12). Some stressed fish also developed corneal ulcers; in such cases, the substantia propria remained intact (Fig. 13).

\section{DISCUSSION}

\section{Distribution of AUR lesions on body surface}

With the fluorescein technique (Noga \& Udomkusonsri 2002), we were able to locate skin ulceration in 

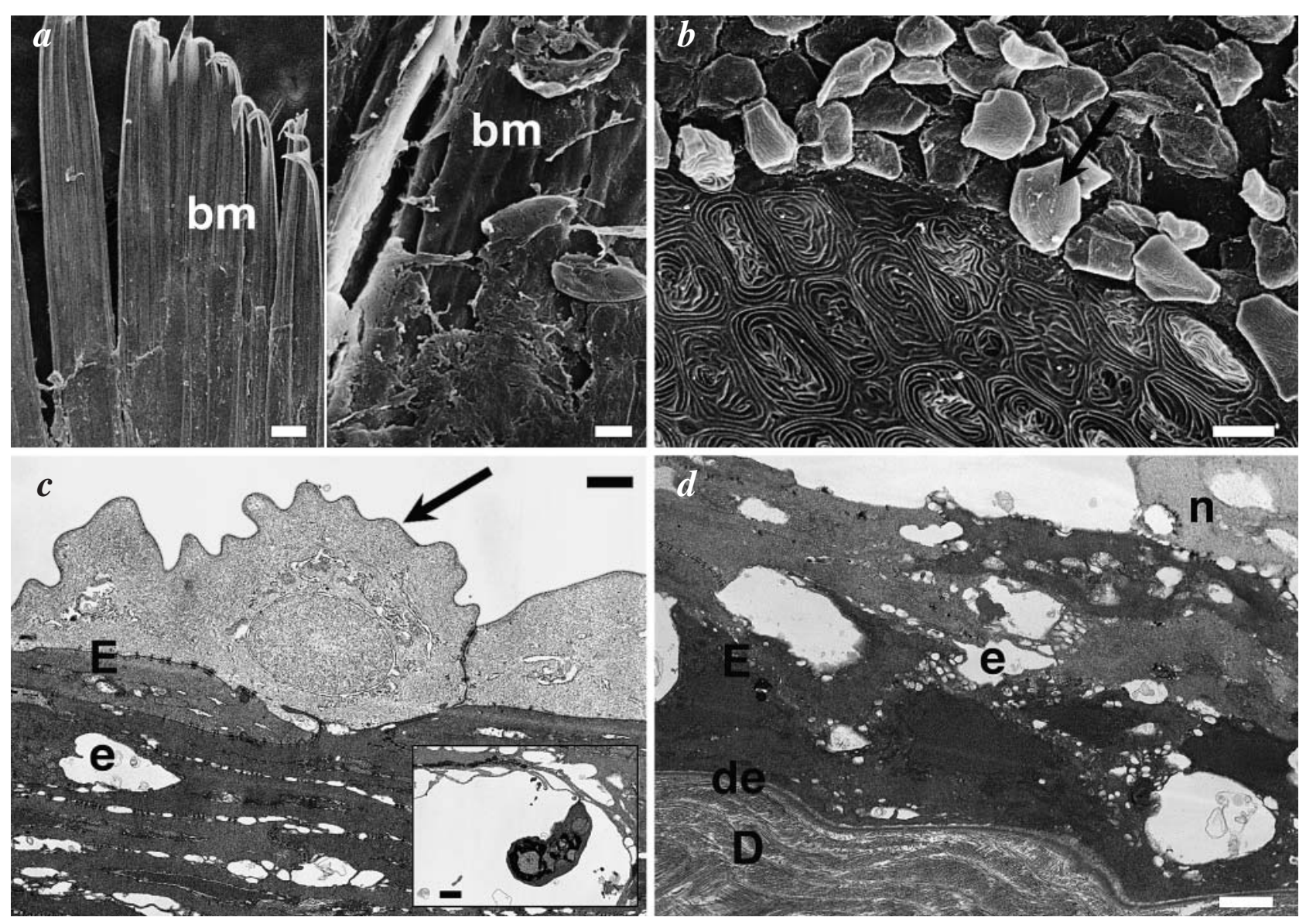

Fig. 10. Morone saxatilis male $\times$ M. chrysops female. Caudal fins of hybrid striped bass confined for 30 min. (a) Left: SEM showing epidermal erosion and ulceration near distal tip of fin; right: epidermal erosion and ulceration, and exposure of basement membrane beneath sloughing epidermis. (b) SEM showing swollen epidermal cells lacking microridges (arrow); this area was adjacent to an epidermal ulcer. (c) TEM of epidermis; note swollen epidermal cells (arrow) and intercellular edema in middle layer of epidermis. Inset: apoptotic body present in basal layer. (d) TEM of epidermis; note necrotic cell and loss of microridges on outer surface. bm: basement membrane; de: desmosome; e: intercellular edema; n: necrotic cell; D: dermis; E: epidermis. Scale bars $=$ (a) left: $350 \mu \mathrm{m}$; right: $6 \mu \mathrm{m}$, (b) $30 \mu \mathrm{m}$, (c) $1.6 \mu \mathrm{m}$ (inset = $1.1 \mu \mathrm{m}$ ), (d) $2 \mu \mathrm{m}$

stressed hybrid striped bass rapidly and accurately. In addition to readily documenting the extent of damage to all affected fins, this technique led us to discover that certain areas of the skin on the body proper were also affected by AUR (Fig. 3). In our preliminary study of AUR lesions (Noga et al. 1998), we did not detect any damage on the body; however, we examined the skin by classical histological methods, and our choice of sites did not happen to include any affected by AUR.

In our present study, we clearly observed ulceration on a number of areas of the body in most fish exposed to acute confinement. The most severely affected area on the body appeared to be the ventrum just dorsal to the anus (Fig. 12). Interestingly, this is the most common site of ulcers in Atlantic menhaden Brevoortia tyannus affected with ulcerative mycosis (UM) (Noga et al. 1988). Ulcerative mycosis lesions are typically deep, aggressive ulcers with a prominent water mold (e.g. Aphanomyces invadans) component. Speculation as to why UM lesions are so common in this region has included possible chemo-attraction of water molds to this area due to release of waste products from the anus (Noga et al. 1988). However, if the menhaden epidermis at this site is more susceptible to stress-related damage, environmental factors (stressors) may be the major reason for this phenomenon.

Another dramatic response to acute stress that we detected with the fluorescein test was corneal damage. The corneal epithelium is very important for maintenance of corneal transparency and ocular osmotic balance. Removal of the corneal epithelium results in an increase of aqueous humor osmolality in marine fishes and a decreased osmolality in freshwater fishes; it also can cause corneal edema and cataracts within 24 h (Ubels \& Edelhauser 1987). Such sequelae can severely impair vision, affecting behavior and the ability 

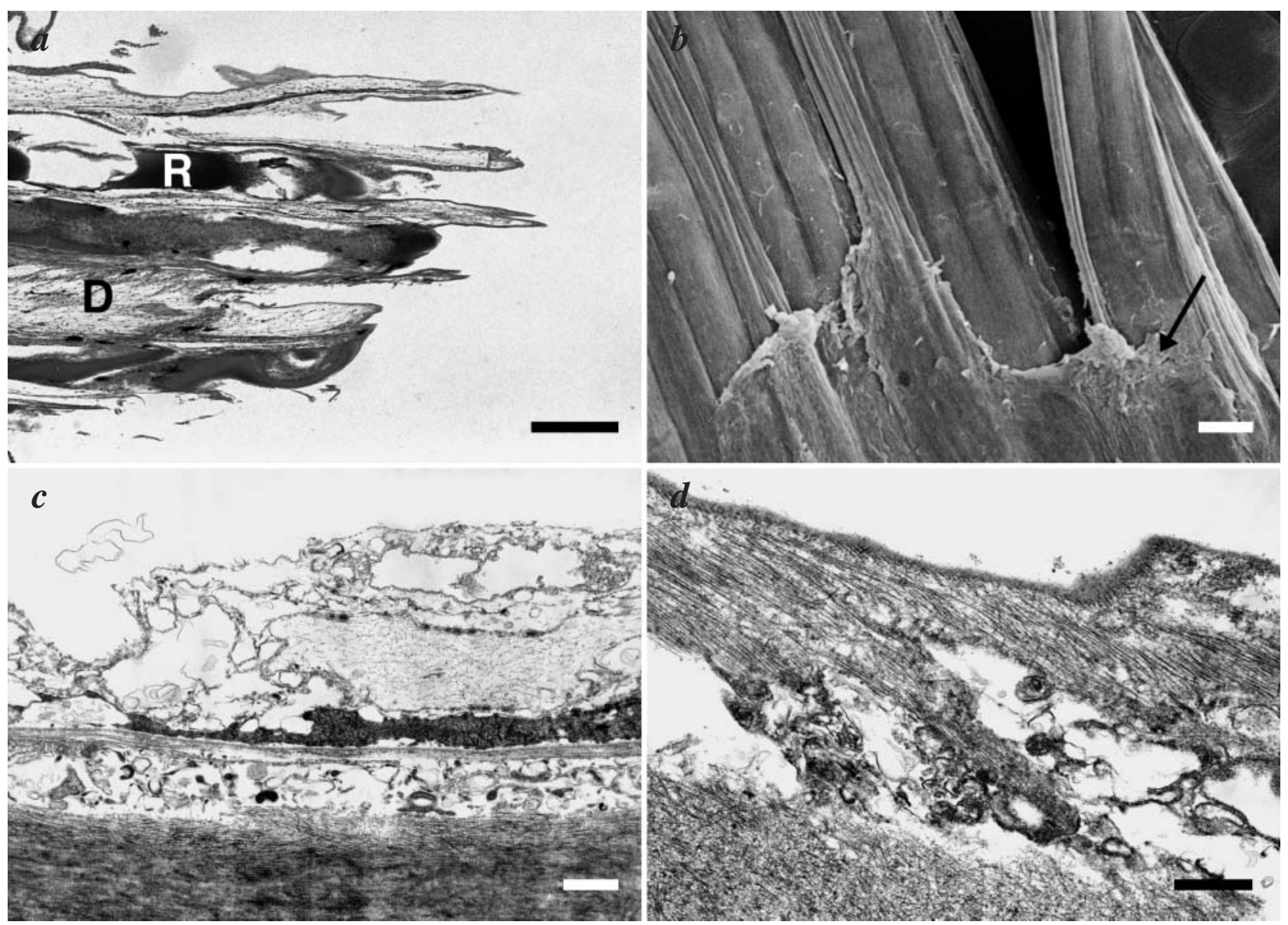

Fig. 11. Morone saxatilis male $\times$ M. chrysops female. Caudal fins of hybrid striped bass confined for 120 min. (a) Fin after 120 min stress, showing ulceration of distal fin tissues and dermal/hypodermal edema (H\&E). D: dermis; R: fin ray. (b) SEM showing severe epidermal sloughing (arrow). (c) TEM showing epidermal degeneration, necrosis, and hypodermal edema. (d) TEM of severe epidermal ulceration showing total loss of epidermis and basement membrane. Scale bars = (a) $200 \mu \mathrm{m}$, (b) $500 \mu \mathrm{m}$, (c) $1 \mu \mathrm{m}$, (d) $1.5 \mu \mathrm{m}$

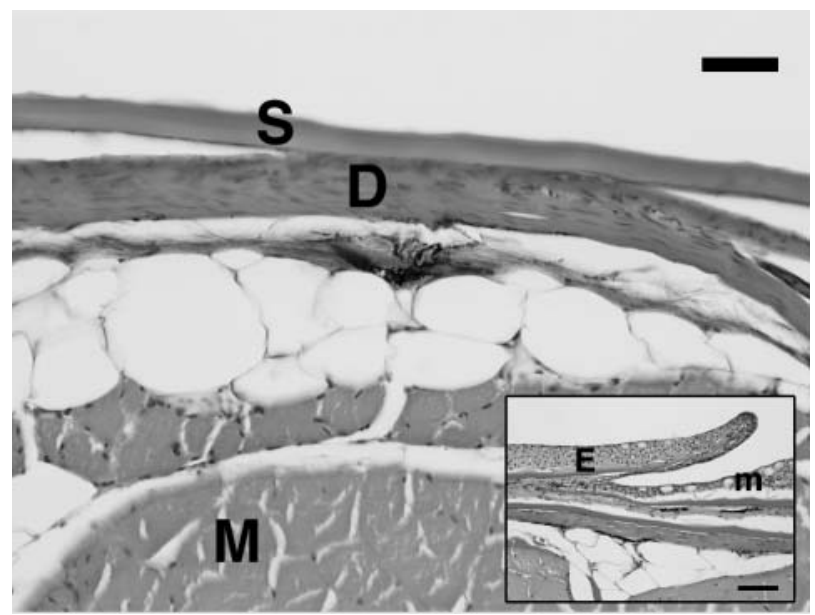

Fig. 12. Morone saxatilis male $\times$ M. chrysops female. Ventrum skin of hybrid striped bass after $2 \mathrm{~h}$ of stress; note complete loss of epidermis. Inset: control (unstressed) fish. D: dermis; E: epidermis; M: muscle; m: mucus cells; S: scale. Scale bars $=200 \mu \mathrm{m}$ and $100 \mu \mathrm{m}$ (inset)

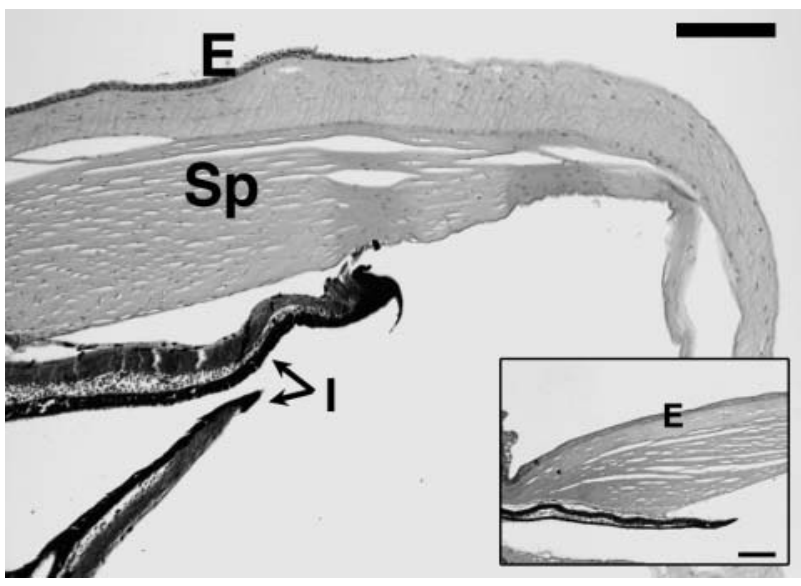

Fig. 13. Morone saxatilis male $\times M$. chrysops female. Cornea of eye of hybrid striped bass showing corneal ulceration after 120 min confinement stress. Inset: cornea of unstressed (control) hybrid striped bass showing intact cornea with several epithelial layers. E: corneal epithelium; I: iris; Sp: substantia propria. Scale bars $=200 \mu \mathrm{m}$ and $100 \mu \mathrm{m}$ (inset) 
to feed. In previous studies, we observed that striped bass Morone saxatilis and hybrid striped bass (M. saxatilis female $\times M$. chrysops male and $M$. saxatilis female $\times M$. americana male) developed corneal cloudiness (presumably edema) when subjected to a $45 \mathrm{~min}$ confinement (Noga et al. 1994). Largemouth bass Micropterus salmoides transported under conditions of high density (120 g fish $\mathrm{l}^{-1}$ water) also developed corneal cloudiness (Brandt \& Jones 1986). However the tissues were never examined histologically in either of these studies to confirm the exact lesions present. Brandt \& Jones (1986) speculated that the cause of this damage was abrasion of the corneal epithelium by contact with other fish, nets and the sides of tank under crowded conditions, but our findings indicate that such trauma is not needed to cause severe corneal damage.

In previous studies, we found that striped bass and hybrid striped bass (Morone saxatilis female $\times$ M. chrysops male), $24 \mathrm{mo}$ and 310 to $390 \mathrm{~mm}$ in total length, developed the most severe fin ulceration on the pectoral and caudal fins, followed by the dorsal fins and then the anal fins, after $2 \mathrm{~h}$ stress (Noga et al. 1998). This is somewhat similar to our current findings using much smaller fish, where the incidence of fin ulceration was greatest in the caudal fins, followed by the dorsal, pectoral, pelvic and anal fins, in that order (Fig. 5). As in our previous study (Noga et al. 1998), there was no evidence that the AUR lesions were induced by trauma. We closely observed all fish during confinement. Fish rarely, if ever, contacted the sides of the cage, and we nevertheless consistently observed a clear and rapid appearance of these lesions on the fins, including those that never contacted any cage surface (e.g. the dorsal fin).

Sharples \& Evans (1996) also found that goldfish Carassius auratus showed fin erosion and ulceration mostly on the pectoral and caudal fins after being chronically subjected to pulp-mill effluent. The severity of damage on different fin types is probably affected by physiological differences related to the microenvironment of the different fins, which in turn is probably influenced by fish species and other factors.

\section{Skin damage caused by stress: AUR versus other reported lesions}

Pathological changes in fin and body skin have been reported in response to a number of stressors such as stress hormones, temperature change and polluted water (Table 1) (Iger et al. 1994a,b,c,d, 1995, Bodammer 2000). When rainbow trout Oncorhynchus mykiss were fed a cortisol-treated diet, plasma cortisol levels increased and was associated with increased shedding of epidermal cells, pigment dispersion, and increased apoptosis of lymphocytes, mucus cells and epidermal cells (Iger et al. 1995). Water temperature can also affect epidermal thickness and the size and number of mucus cells. Rainbow trout exposed to temperature elevated from 15 to $22^{\circ} \mathrm{C}$ for $3 \mathrm{~h}$ displayed decreased skin thickness within 3 h (Iger et al. 1994a). After 24 h, skin thickness was restored; it then continued to increase until Day 4. Both necrotic and apoptotic cells appeared in the stressed epidermis. When

Table 1. Stressors linked to ultrastructural changes in fish skin

\begin{tabular}{|c|c|c|c|c|}
\hline Stressor & Species & $\begin{array}{l}\text { Stress } \\
\text { period }\end{array}$ & $\begin{array}{l}\text { Skin lesion } \\
\text { reported }\end{array}$ & Source \\
\hline Hypercortisolemia & $\begin{array}{l}\text { Rainbow trout } \\
\text { Oncorhynchus mykiss }\end{array}$ & $3.5 \mathrm{~h}-7 \mathrm{~d}$ & $\begin{array}{l}\text { Apoptosis of mucus and epidermal cells; } \\
\text { shedding of epidermis; lymphocyte infiltration; } \\
\text { melanosome migration }\end{array}$ & Iger et al. (1995) \\
\hline Hyperthermia & Rainbow trout & $3 \mathrm{~h}$ & $\begin{array}{l}\text { Decreased skin thickness; apoptotic and } \\
\text { necrotic epidermal cells; lymphocyte infiltra- } \\
\text { tion and migration of macrophage in both epi- } \\
\text { dermis and dermis; later hyperplasia of skin }\end{array}$ & Iger et al. (1994b) \\
\hline Hyperthermia & Minnow Phoxinus phoxinus & $3-6$ mo & $\begin{array}{l}\text { Decreased skin thickness and mucus cell } \\
\text { number; increased club-cell number }\end{array}$ & Fantin et al. (1984) \\
\hline Hypothermia & Minnow & $3-6 \mathrm{mo}$ & $\begin{array}{l}\text { Increased size and number of mucus cells, and } \\
\text { the skin thickness; hypertrophy of club cells }\end{array}$ & Fantin et al. (1984) \\
\hline Polluted water & Rainbow trout & $4 \mathrm{~h}-24 \mathrm{~d}$ & $\begin{array}{l}\text { Decreased skin thickness and later skin hyper- } \\
\text { plasia; apoptotic and necrotic epidermal cells; } \\
\text { lymphocyte infiltration in epidermis and dermis }\end{array}$ & Iger et al. (1994a) \\
\hline Pulp mill effluents & Goldfish Carassius auratus & Chronic & $\begin{array}{l}\text { Necrosis of epidermis; disrupted basement } \\
\text { membrane; edema, necrosis and hyperemia of } \\
\text { dermis }\end{array}$ & $\begin{array}{l}\text { Lindesjöö \& Thulin } \\
\text { (1994) }\end{array}$ \\
\hline Pulp mill effluents & Goldfish & Chronic & $\begin{array}{l}\text { Loss of cuticle; necrosis and sloughing of } \\
\text { epidermis; epidermal and dermal edema }\end{array}$ & $\begin{array}{l}\text { Sharples \& Evans } \\
\text { (1996) }\end{array}$ \\
\hline
\end{tabular}


minnows Phoxinus phoxinus L. were exposed to high temperature $\left(22^{\circ} \mathrm{C}\right)$, skin thickness and the number of mucus cells decreased, but club cell numbers increased (Fantin et al. 1984). In contrast, when minnows were exposed to low temperature $\left(12^{\circ} \mathrm{C}\right)$, the skin increased in thickness, the size and number of mucus cells increased, and the club cells were hypertrophied. Rainbow trout displayed significantly decreased epidermal thickness after exposure to polluted Rhine River water for 7 d (Iger et al. 1994b) while the epidermis was hyperplastic after $24 \mathrm{~d}$ exposure. The most severe lesion observed was erosion; however, none of the above studies reported skin ulceration.

Epidermal ulceration has been observed in goldfish chronically exposed to bleached mill effluent (Lindesjöö \& Thulin 1994, Sharples \& Evans 1996). The goldfish presented dermal hyperemia, necrosis and edema in the fin lesions. Melanophores and lymphocytes were also found in the erosive fins. It has been suggested that a vascular change in the dermis possibly affected blood supply and caused ischemia, leading to degenerative changes in the epidermis, and that spongiosis probably resulted from an inflammatory response in the chronically stressed skin (Murchelano 1975, Roberts 1989, Lindesjöö \& Thulin 1994).

In contrast to all the above studies by other investigators, in which skin damage was relatively mild (nonulcerated) or required long periods (at least days) to develop, the AUR causes extremely rapid and very severe damage, and affects all body surfaces, including the fins, body proper and eyes. Ulcerative lesions were detectable within 15 min of acute stress (Fig. 9), which is a surprisingly short time for such lesions to develop. The rapidity of this response has important implications for the risk of fish becoming sick after an acute stress. Apparently even an extremely transient stress can lead to skin ulceration. Thus, even very brief stresses such as confining, transporting or handling a fish for only $15 \mathrm{~min}$ have the potential to lead to AUR; furthermore, we have evidence that AUR dramatically increases the susceptibility of fish to some infectious diseases (P. Udomkusonsri \& E. J. Noga unpubl.).

\section{Possible mechanisms responsible for AUR}

The rapidity with which AUR developed in experimentally stressed fish suggests that a very severe perturbation of homeostasis is needed for this response. The earliest detectable lesion in affected fish was swelling and sloughing of the outer epidermal layer (Fig. 9). The cytoplasm of necrotic cells of the outer epidermal layer appeared transparent (Fig. 9c). This typically results from the inability of cells to control the influx of water and from outflow of cellular proteins (Wyllie et al. 1980, Frenkel et al. 1999). While both necrosis and apoptosis appeared to play a role in epidermal loss with AUR, necrosis was more common by far.

Necrosis is a cellular response to a severe insult, and triggers the inflammatory response in damaged tissue, while apoptosis is a noninflammatory, programed cell death that is associated with embryogenesis, metamorphosis, and normal cell turnover (Wyllie et al. 1980). Necrosis typically occurs in response to toxins, hypoxia, or ischemia, and affects cells in groups rather than singly (Wyllie et al. 1980, Anilkumar et al. 1992). Apoptosis is controlled by genetic and normal physiological stimuli, such as endocrine changes (e.g. cortisol, ACTH) (Iger et al. 1992, 1995, Wyllie 1997) and toxic agents such as radiation or chemotherapeutic agents (Anilkumar et al. 1992). We observed apoptosis in scattered, single cells in the epidermis, while necrotic epidermal cells were found in much larger numbers, especially on the outer surface of the epidermis. These data suggest that AUR is mainly a necrotic event.

Apoptotic bodies are usually phagocytosed and digested by resident cells (Anilkumar et al. 1992). Iger et al. (1994c) reported that autophagocytic vesicles with apoptotic cells, inside the epidermal cells of both unstressed and stressed fish, were eliminated by the epidermal cells. Thus, the autophagocytic vesicles in the epidermal cells in our study support our observation of apoptosis in both unstressed and stressed fish. Apoptotic cells in unstressed fish indicate the normal turnover of epidermis.

In our study, leukocytes were found in the basal layer of the epidermis and close to the basement membrane in some control, unstressed fish. We used the term 'leukocyte' since we found mainly lymphocytes, but also mast cells and neutrophils, in the epidermis. In stressed fins, we found leukocytes not only close to the basement membrane, but also in the upper layers of the dermis. Lymphocyte infiltration probably represented a non-specific immune response to the acute stress (Iger et al. 1994a); however, the mechanisms regulating this lymphocyte infiltration are unknown. It is possible that the necrotic cells in stressed fish may release their cytoplasmic contents into the intercellular space, signaling the migration of inflammatory cells into the affected areas. Although there is no information on whether fish leukocytes can infiltrate the epidermis of skin within $2 \mathrm{~h}$, it is possible that these leukocytes migrated from the blood to the dermis and then to the basal layer of the epidermis. Melanophore aggregation in the dermis might also be a response to stress (Iger et al. 1994c). This phenomenon may represent an additional defense mechanism, since melanin pigments have bactericidal activity (Ellis 1977). 
During stress, epinephrine is released from chromaffin cells and causes physiological changes to help the fish survive in a stressful environment (Wendelaar Bonga 1997). Epinephrine affects vascular resistance by acting on alpha-adrenoceptors, causing vasoconstriction. Epinephrine causes vasoconstriction in the tail fin of the eel Anguilla australis Phillips and the Atlantic cod Gadus morhua (Davie 1981, Wahlqvist \& Nilsson 1981). Also, hybrid striped bass injected with epinephrine develop a mild form of AUR (Noga et al. 1998), suggesting that the adrenergic response may play a role in this response. We previously suggested that peripheral blood vessels may constrict and that affected tissues might then become hypoxic, even in adequately oxygenated water (Noga et al. 1998). Since the epidermis is usually avascular (Ferguson 1989, Roberts 2001), any vascular disturbances must be due to pathological changes in the dermis. It is possible that when hybrid striped bass are acutely stressed, the peripheral vasculature is constricted by the effect of epinephrine, causing the epidermis to become hypoxic or ischemic, resulting in degenerative changes in the epithelial tissues including the corneal epithelium.

Skin ulcers are one of the most useful biomarkers of polluted or stressful environments (Sindermann 1990, Bernet et al. 1999, Noga 2000). Since the skin of fish covers the entire body and fins, and is metabolically active and rapidly responds to stressors (Whitear 1986, Iger et al. 1994b), this epidermal damage may occur via either direct contact with toxicants, or indirectly due to physiological changes. Furthermore, the skin of hybrid striped bass and other fishes serves as a primary defense mechanism that contains specific and nonspecific defense factors, such as immunoglobulins, lectins, complement-like proteins, lysozyme and antimicrobial polypeptides (Yano 1996, Robinette \& Noga 2001). After fishes lose their protective skin barrier, opportunistic bacteria (e.g. Aeromonas spp. and Pseudomonas spp.), parasites, viruses and water molds (Saprolegnia spp.) can invade the skin and cause infection (Plumb 1997). Skin loss also causes a serious osmotic stress due to loss of the protective barrier. Thus, AUR might predispose fishes to many explosive epidemics of opportunistic skin pathogens, which can cause morbidity and mortality in acutely stressed fishes.

In addition, the fact that severe skin ulceration can occur very soon after a fish is captured, has important implications for environmental monitoring, since the process of capture might cause inapparent, yet serious harm to sampled populations that are subsequently released after examination. Such considerations are also relevant to the commonly used catch-and-release strategy in recreational fisheries. The skin damage caused by AUR might also confound interpretation of skin damage in environmental monitoring programs.
'Fin erosion' is one of the most common pollutionassociated pathologies (Sindermann 1990), but the effect of AUR has not been previously considered. Thus, diagnoses of 'fin erosion' in such programs need to be critically examined in the light of our findings.

Acknowledgements. We thank L. Brothers (Carolina Fisheries, Aurora, North Carolina) for supplying hybrid striped bass. This work was supported by Research Grant No. US-3030-98 from BARD, the United States-Israel Binational Agricultural Research and Development Fund; by Grant \#NA46RG0087 from the National Sea Grant College Program, National Oceanic and Atmospheric Administration, to the North Carolina Sea Grant College Program; and by the USDA-NRI Competitive Grant Program (Project \#97-35204-7722). P.U. is a Fellow of the Royal Thai Government.

\section{LITERATURE CITED}

Agresti A (1996) An introduction to categorical data analysis. Wiley-Interscience, New York

Anderson P, Van Heukelem W, Harrell RM (2001) Performance evaluation of hybrid striped bass and two superior strains of striped bass Morone saxatilis in a flowthrough system. In: Society WA (ed) Aquaculture 2001: book of abstracts. JM Parker Coliseum, Louisiana State University, Baton Rouge, LA, p 19

Anilkumar TV, Sarraf CE, Alison MR (1992) The biology and pathology of programmed cell death (apoptosis). Vet Hum Toxicol 34:251-254

Beccera J, Montes GS, Rexiga SRR, Junqueira LCU (1983) Structure of the tail fin in teleosts. Cell Tissue Res 230: 127-137

Berger RL (1996) More powerful tests from confidence interval p values. Am Statistn 50:314-318

Bernet D, Schmidt H, Meier W, Burkhardt-Holm P, Wahli T (1999) Histopathology in fish: proposal for a protocol to assess aquatic pollution. J Fish Dis 22:25-34

Bodammer JE (2000) Some new observations on the cytopathology of fin erosion disease in winter flounder Pseudopleuronectes americanus. Dis Aquat Org 40:51-65

Brandt TM, Jones RM (1986) Corneal cloudiness in transported largemouth bass. Prog Fish-Cult 48:199-201

Carlberg JM, Van Olst JC, Massingill MJ (2000) Hybrid striped bass: an important fish in US aquaculture. Aquac Mag 26:26-38

Davie PS (1981) Vasculature resistance responses of an eel tail preparation; alpha constriction and beta dilation. J Exp Biol 90:65-84

Ellis AE (1977) The leucocyte of fish: a review. J Fish Biol 11: 453-491

Fantin AMB, Trevisan P, Bagatoli M (1984) Effect of environmental temperature on the epidermis of minnow Phoxinus phoxinus L. Zool Jahrb Abt Anat Ontag Tiere 111:357-367

Ferguson HW (1989) Systemic pathology of fish. Iowa State University Press, Ames, IA

Frenkel V, Kimmel E, Iger Y (1999) Ultrasound-induced cavitation damage to external epithelia of fish skin. Ultrasound Med Biol 25:1295-1303

Groman DB (1982) Histology of the striped bass. American Fisheries Society, Bethesda, MD

Harrell RM, Webster DW (1997) An overview of Morone culture. In: Harrell RM (ed) Striped bass and other Morone culture. Elsevier, Amsterdam, p 1-10 
Iger Y, Hilge V, Abraham M (1992) The ultrastructure of fishskin during stress in aquaculture. In: Moav B, Hilge V, Rosenthal H (eds) Progress in aquaculture research. European Aquaculture Society, Ostend

Iger Y, Jenner HA, Wendelaar Bonga SE (1994a) Cellular response in the skin of rainbow trout (Oncorhynchus mykiss) exposed to temperature elevation. J Fish Biol 44: 921-935

Iger Y, Jenner HA, Wendellaar Bonga SE (1994b) Cellular response in the skin of rainbow trout (Oncorhynchus mykiss) exposed to Rhine water. J Fish Biol 45:1119-1132

Iger Y, Lock RAC, Jenner HA, Wendellaar Bonga SE (1994c) Cellular responses in the skin of carp (Cyprinus carpio) exposed to copper. Aquat Toxicol (Amst) 29:49-64

Iger Y, Lock RA, van der Meij JC, Wendelaar Bonga SE (1994d) Effects of water-borne cadmium on the skin of the common carp (Cyprinus carpio). Arch Environ Contam Toxicol 26:342-350

Iger Y, Balm PH, Jenner HA, Wendelaar Bonga SE (1995) Cortisol induces stress-related changes in the skin of rainbow trout (Oncorhynchus mykiss). Gen Comp Endocrinol 97:188-198

Lindesjöö E, Thulin J (1994) Histopathology of skin and gills of fish in pulp mill effluents. Dis Aquat Org 18:81-93

Murchelano RA (1975) The histopathology of fin rot disease in winter flounder from the New York Bight. J Wildl Dis 11: 263-268

Noga EJ (2000) Skin ulcers in fish: Pfiesteria and other etiologies. Toxicol Pathol 28:807-823

Noga EJ, Udomkusonsri P (2002) Fluorescein: a rapid, sensitive, nonlethal method for detecting skin ulceration in fish. Vet Pathol 39:726-731

Noga EJ, Levine JF, Dykstra MJ, Hawkins JH (1988) Pathology of ulcerative mycosis in Atlantic menhaden Brevoortia tyrannus. Dis Aquat Org 4:189-197

Noga EJ, Kerby JH, King W, Aucoin DP, Giesbrecht F (1994) Quantitative comparison of the stress response of striped bass (Morone saxatilis) and hybrid striped bass (Morone saxatilis $\times$ Morone chrysops and Morone saxatilis $\times$ Morone americana). Am J Vet Res 55:405-409

Noga EJ, Botts S, Yang MS, Avtalion R (1998) Acute stress

Editorial responsibility: Carl Schreck,

Corvallis, Oregon, USA causes skin ulceration in striped bass and hybrid bass (Morone). Vet Pathol 35:102-107

Plumb JA (1997) Infectious diseases of striped bass. In: Harrell RM (ed) Striped bass and other Morone culture. Elsevier Science BV, Amsterdam, p 271-313

Quilhac A, Sire JY (1999) Spreading, proliferation and differentiation of the epidermis after wounding a cichlid fish, Hemichromis bimaculatus. Anat Rec 254:435-451

Roberts RJ (1989) The pathophysiology and systemic pathology of teleosts. In: Roberts RJ (ed) Fish pathology. Bailliere Tindall, London, p 56-134

Roberts RJ (2001) Fish pathology, Harcourt Publishers, London

Robinette DW, Noga EJ (2001) Histone-like protein: a novel method for measuring stress in fish. Dis Aquat Org 44: 97-107

Sharples AD, Evans CW (1996) Pathology of fin erosion in goldfish Carassius auratus. Dis Aquat Org 24:81-91

Sindermann CJ (1990) Principal diseases of marine fish and shellfish, 2nd edn, Vol 1. Academic Press, New York

Ubels JL, Edelhauser HF (1987) Effects of corneal epithelial abrasion on corneal transparency, aqueous humor composition, and lens of fish. Prog Fish-Cult 49:219-224

Wahlqvist I, Nilsson S (1981) Sympathetic nervous control of the vasculature in the tail of the Atlantic cod, Gadus morhua. J Comp Physiol 144:153-156

Wendelaar Bonga SE (1997) The stress response in fish. Physiol Rev 77:591-625

Whitear M (1986) The skin of fish including cyclostomesepidermis. In: Bereiter Hahn J, Matoltsy AG, Richards KS (eds) Biology of integument, Vol 2, Vertebrates. SpringerVerlag, Heidelberg, p 8-38

Wyllie AH (1997) Apoptosis: an overview. Br Med Bull 53: 451-465

Wyllie AH, Kerr JFR, Currie AR (1980) Cell death: the significance of apoptosis. In: Bourne GH, Danielli JF (eds) International review of cytology. Academic Press, New York, p 251-306

Yano T (1996) The nonspecific immune system: humoral defense. In: Hoar WS, Randall DJ, Farrell AP (eds) The fish immune system: organism, pathogen, and environment. Academic Press, San Diego, CA, p 150-157

Submitted: June 2, 2003; Accepted: April 27, 2004

Proofs received from author(s): October 6, 2004 